\title{
EQUILIBRIUM
}

Quarterly Journal of Economics and Economic Policy

2016 VOLUME 11 ISSUE 3, September

p-ISSN 1689-765X, e-ISSN 2353-3293

www.economic-policy.pl

Czech, S. (2016). Choice Overload Paradox and Public Policy Design. The Case of Swedish Pension System. Equilibrium. Quarterly Journal of Economics and Economic Policy, 11(3), 559-584. DOI: http://dx.doi.org/10.12775/EQUIL.2016.025

Sławomir Czech*

University of Economics in Katowice, Poland

\section{Choice Overload Paradox and Public Policy Design. The Case of Swedish Pension System}

JEL Classification: D19; H44; H55

Keywords: extensive choice; cognitive limitations; market failure; choice architecture; funded pensions

\begin{abstract}
In this paper we focus on an adverse effect of extensive choice widely known as 'choice overload'. We draw on the case of Swedish funded pensions for illustration and analyze the consequences of the design that allowed for maximizing the choice set. The analysis shows limitations of employing the rational choice approach to the real choice decisions biased with common psychological factors and demonstrates that government's responsibility for the privatized pension system does not end with the design. We also emphasize the need for a decent default option, which would mitigate socially harmful results of adverse behavior effects like procrastination, status quo bias or abstaining from choice. After all, privatized pension systems still belong to the sphere of public policy.
\end{abstract}

(C) Copyright Institute of Economic Research

Date of submission: May 15, 2015; date of acceptance: April 26, 2016

*Contact: slawomir.czech@ue.katowice.pl, University of Economics in Katowice, 1 Maja 50, 40-287 Katowice, Poland 


\section{Introduction}

Decisions of choice are one of the key issues of economics. Sound choices contribute to increased welfare of groups and individuals, determine the efficiency of economic endeavors, and are essential for society's long-term economic development. In psychological terms, enjoying the possibility of choice provides a sense of personal control over one's life and fuels intrinsic motivation for purposeful actions leading to increased task enjoyment and performance. The choice itself reassures our perception of environment control and self-efficacy stemming from our very biological condition (Leotti et al., 2010). Many choice options are thus usually presumed to be desirable and beneficial. Yet, as recent literature suggests, this belief has serious limitations. An overabundance of choice possibilities can lead to adverse effects both in consumption decisions and life satisfaction (Schwartz, 2004). In contrast, constraints imposed on choice sets facilitate the process of decision making and increase subsequent satisfaction.

This choice dialectics had seemed so far rather detached from the public sphere, as the state usually provided beneficiaries of public policies with very limited choice compared to the amount of goods and services offered by markets. However, the recent turn in welfare policies assumed that they should become more choice-oriented, just like the critics of public monopolies and standardization demanded. This way what seemed to be an exclusive issue of consumer choice and marketing strategies entered the arena of public policy (see Lynch \& Zauberman, 2006). As a result, the questions of 'choice architecture' have become increasingly important as well as the need of rethinking government's role and responsibility when it comes to designing public policies of marketized welfare state (Thaler \& Sunstein, 2009).

This paper aims at broadening our understanding of the choice overload phenomenon, by examining the case of the Swedish pension system. It illustrates the fact that privatization of the public sphere brings not only benefits, but also market failures that used to be addressed by traditional welfare states. We also show the shortcomings of employing the principles of rational choice into real world situations, like the choice architecture of pension savings system. On this background, we point to the consequences of this phenomenon being cast on government's role and responsibility in a democratic state.

The paper is organized as follows. The second section provides brief information on the methodology of research. The third section reviews the latest literature on choice overload, sketching the current state of the art. The third section discusses the question of choice in modern welfare state 
policies focusing on pension systems. The fourth section presents shortly the general design of the Swedish pension reform. The fifth section scrutinizes on the Swedish premium pension system and observes the overload effect. The final section concludes.

\section{Research Methodology}

The methodology of this research draws both on literature study and data analysis, which is reflected in the paper's structure. Theoretical sections review the latest literature on the choice overload effect published mainly in journals committed to consumer research and psychology of economic agents. This way, the model of homo economicus, which is usually employed in economics, can be contrasted with empirical research coming from outside of pure economics. The subsequent discussion on introducing choice into public policies is based on this approach as well.

The sections devoted to the Swedish case of premium pensions draw on empirical material. We use the latest data published by the Swedish Pension Authority, which include data statistics to be found on the Authority's webpage (www.pensionsmyndigheten.se) and official publications on pensions (inter alia annual pension reports named Premiepensionen - Pensionsspararna och pensionärerna). Unfortunately, since 2012 the annual reports have been published in a shorter form, and thus some data is missing. We also make use of official government reports and directives evaluating the performance of the pension system and recommending desirable changes therein.

\section{Choice Overload and the Limits of homo economicus}

The standard economic model of rational choice is based on a number of simplifying assumptions (see for example Schotter, 2009). An economic agent is, for example, aware of all of the choice options that are available to him and displays no cognitive limitations in processing and ordering them. Driven by expected utility maximization, he takes decision that are always optimal given existing constraints. His preferences are stable and do not depend on the context. Being a self-oriented actor, he does not take into consideration the utility of others nor the existing social structures. However, this view of an economic agent, a fictional character usually referred to as the model of homo economicus, is an abstract construction designed for 
a specific kind of scientific reasoning, preferably to be employed in formal modeling, and modern economics is rather well aware of this caveat (O'Boyle, 2007; Thaler, 2000). As a matter of fact, a whole branch of economic science - behavioral economics - has been developed in order to trace the inconsistencies of this model with respect to reality, searching why people behave differently from what the model predicts and what it means for economic theory and praxis (see Wilkinson, 2008 for a comprehensive introductory text). So even though some scholars argue that models of rational choice are nowadays flexible enough to incorporate the critical insights and still prove to be useful in explaining economic phenomena (Gilboa, 2010), one has to be aware of their limitations for they were not designed to reflect the reality of human nature, but for the sake of particular scientific cognition.

An example of the phenomenon that the theory of rational choice fails to explain is the situation in which an agent faces excessive choice options which actually deter him from making an informed and rewarding choice. In effect, he does not maximize his utility, because he falls short of being a perfect calculating machine. This stands in opposition to the claim that a large number of options to choose from contributes to an increased welfare of individuals. Following the logic of standard economic model, for a numerous population of individuals holding various preferences, the greater set of choice, the better. In this situation each and every individual has the possibility to examine the choice set for himself and choose an option that fits him best, leading in aggregate terms to the lowest general welfare loss possible. Preferences of most people are met and thus the highest utility for all is achieved. The relation between preferences, choices and individual welfare is, however, not so straightforward. Firstly, satisfaction of interests does not have to imply increased welfare (Hausman, 2012). And secondly, individuals facing extensive number of options have lowered motivation to choose and achieve lower level of contentment than previously expected. More choice does not have to automatically imply that people will be better-off with it (Botti \& Iyengar, 2006).

Recent literature has grouped negative effects of choosing from an extensive number of options under term 'choice overload'. These effects usually include abstaining from making a choice decision, lower satisfaction derived from one's choice and feeling of regret after making a choice. The choice overload paradox has originally derived from consumer research. In a seminal paper Iyengar and Lepper (2000) reported the findings of three experimental studies in which participants made choices from a differentiated sets of choice options. They found that too much choice was a negative factor in choosing and buying products. While at first vast array of 
choice seemed attractive and desirable, it turned detrimental for actual behavior and decision making. Participants made more confident decisions when their choice was limited: they felt more inclined to purchase items, reported higher satisfaction from the decision made, and performed better with tasks chosen from a limited set of possibilities. Too much choice, on the other hand, caused decision paralysis, poor decision quality and feelings of regret due to rising opportunity costs and escalation of expectations. The feelings of regret were confirmed in the studies of Sagi and Friedland (2007), who found that regret is positively related with rising number of alternatives and their diversity, and of Haynes (2009), who observed that larger set of alternatives led to decreasing satisfaction from the choices made. A number of adverse effects of choice overload was also found by Vohs et al. (2008) who demonstrated that choosing among many alternatives is effortful and depletes cognitive resources leading to deterioration in self-control, stamina and pain tolerance, persistence in the face of failure, and performance in numerical calculations.

A number of earlier studies was also very critical of the rationality assumption employed by conventional models of choice, because people's ability to process information is limited and results either in third party influenced choice or in abstaining from choice. Tversky and Shafir (1992) challenged the idea that each alternative is assigned a value, so that an individual can choose the one with the highest rating. In the situation of conflict among the alternatives, one rather tends to defer decision, search for new alternatives, or choose the default option. Dhar (1997) confirmed these findings, stressing the fact that small differences in alternatives between options increase the preference for a no-choice option. Timmermans (1993) found that when faced with increasing number of alternatives, people tend to assimilate less information on the attributes of offered options and to adopt absolute rather than relative comparisons, due to the inability to process such an amount of information ${ }^{1}$. It has also been convincingly argued on philosophical grounds that rational choice theory works best when choice is seriously constrained (Satz \& Ferejohn, 1994). Agents' preferences are not a matter of individual psychology and cognition, but they rather stem from social structures and interests.

When faced with overwhelming choice people tend to defer choice explicitly. Dhar (1997) for example found that expansion of the choice set even by adding more attractive alternatives actually drove people into the no-choice option. Also, when asked to point to the features of alternatives that appeared attractive to choice makers, participants felt discouraged from

\footnotetext{
${ }^{1}$ However, when it comes to comparing interpersonal well-being, it is the relative standing that counts, not the absolute one (Solnick \& Hemenway, 1998).
} 
committing to a firm decision. However, the possibility to choose more than one option increasingly mitigated the effect. A study by Jessup et al. (2009) identified two factors that fostered no-choice decisions. First, people avoid choice when their preferred option changes too often. And second, when time runs out. However, as Anderson (2003) points out, no-choice decision is not a homogenous concept, but may include procrastination, preference for status quo, or trade-off between effort to make a choice and expected benefits. One can also consciously wait for better options to emerge in the future. No-choice can thus be a deliberate - and rational - decision.

The decision to abstain from making a choice may involve staying at the status quo position (Samuelson \& Zeckhauser, 1988; Masatlioglu \& Ok, 2005), which stems either from a direct preference for the status quo or from being overwhelmed by choice options. This bias increases with the number of choice alternatives, which may be perceived as a rational response due to transition costs and uncertain outcomes. Samuelson and Zeckhauser (1998) argue, however, that it is rather psychological factors that discourage people from transition to better allocative positions and we should turn to loss aversion, endowment effect and psychological commitments in explaining this phenomenon.

The choice overload effect can, however, be moderated in certain circumstances and not all experiments were satisfactorily replicated when it came to report negative feelings. Scheibehenne et al. (2009) claim that the effect depends on multiple boundary conditions and interaction between several factors, so even if the choice overload effect exists, it is not as robust as previously thought. The moderators of the effect can be grouped into three categories (Scheibehenne et al., 2010): assortment structure, decision strategies of individuals, and the perception of options' quality. For example, specific arrangement and categorization of options, mindful decision strategies and choosers' heuristics can facilitate the process of choosing. Also Inbar et al. (2011) found evidence that regret from choosing even from a large set of option is eliminated if people have enough time to consider their choice. All this implies that there are important preconditions for the choice overload effect to occur, but there is still no comprehensive study incorporating these factors into a more general theory.

Other studies show that people actually experience the greatest satisfaction when choosing from intermediate set of choices, not too small and not too big. Reutskaja and Hogarth (2009) suggested that with increasing number of alternatives both costs and benefits rise. The difference is, however, that costs tend to escalate, whereas benefits satiate. The discrepancy between them rises, leaving people less satisfied. Also, the change in per- 
ceived costs and benefits will affect the satisfaction function - the framing of options and decision does matter. Similar results were obtained by Reed et al. (2011), who linked the dissatisfaction from extensive choice with effort needed to evaluate options.

\section{Welcoming Choice into Pension Policy Schemes}

For the last three decades policies of welfare state and social security have undergone extensive transformations in many advanced countries. According to the retrenchment slogan, the state was supposed to gradually back off from providing social benefits, because the market-based alternative promised delivery of the same services, only in a cheaper and more effective manner with greater respect to citizens' preferences ${ }^{2}$. The state was thus supposed to guarantee that everybody who was eligible would be provided with social benefits or social assistance, but there was apparently no reason for the state to be the only supplier of such goods and services. It was widely believed that the previous system with public monopolies and uniformed service was inefficient, expensive and of poor quality. In effect, it was not matching the expectations of beneficiaries and offered very limited rewards for professionals employed in welfare services. Introduction of new policies was also expected to lessen the burden for public finances, reduce unnecessary administration and bureaucracy, and eliminate inefficiencies that tend to appear in the public sector.

The policy shift entailed a turn toward more individual approach to recipients; it encouraged private initiative and above all allowed for more personalized choice. However, introducing more choice into welfare policy raised a number of important issues. In principle, the expansion of choice should increase opportunities and enhance equity if we still assume that public policy should increase the welfare of citizens (Le Grand, 2007; Greve, 2009). From this standpoint, more choice can actually be largely useless if it is not possible to use it or only some recipients are able to take advantage of it. Traditional policies of welfare state utilized standardized measures for a reason. They were expected to eliminate market failures by exercising public intervention where there was no well-functioning market and by doing so reduce inequalities for the sake of public good. However, current trends of reintroducing choice can restore previous concerns if done

${ }^{2}$ See Winston et al. (2002) or Pierson (2006, ch. 6) for a brief survey of arguments in favor of retrenchment. 
without thoughtful reflection on how to deal with market failures that can aggravate social divisions in the long-term. One can name several conditions that should be fulfilled to minimize this risk, like wide information access, low transaction costs, right incentive structure, sound design of competition, and social trust (Greve, 2003; 2009), but virtually none of them can be accomplished by mere market forces. They all require the state to take responsibility for institutional design and continuous monitoring of relevant developments in the new public-private sphere of economic activity. Yet even then there is no guarantee that these market failures will be eradicated successfully.

The changes in welfare policies took place in many areas: health care, elderly care and primary to tertiary public education (see: Blomqvist, 2004 for developments in Sweden). However, one of the most far-reaching privatization reforms occurred within pension systems bringing up issues of institutional design and on-going governance (see: Ebbinghaus, 2011). Many countries adopted notional defined contribution scheme complemented with fully or partially funded individual accounts administered by private companies. As a result, large streams of publicly collected funds were directed into private sector for long-term management. Reasons for the reform were numerous and its advantages highly praised. The former usually included society ageing (increasing life expectancy combined with declining fertility), fiscal issues (budget deficits and rising public debt), transformations of labor markets (declining employment rates, growth of non-standard employment contracts and low-paid jobs, persistent unemployment), falling productivity of postindustrial economies, and finally changes in social life (earlier retirement, one-child family, raise of individualistic philosophy of life). New rules were expected to address at least some of these issues thanks to their impact on public finances, financial markets and microeconomic incentives ${ }^{3}$. For example the adoption of defined contribution principle assumed that annuities could be adjusted to the existing demographic and economic conditions so that public finances would be more sustainable facing adverse shocks. The new system would also contribute to higher economic growth through increased savings and development of capital markets.

Expected benefits concerned not only the macro level, but individuals were supposed to be better-off as well. With respect to funded accounts pension, savers were granted choice that they did not have in the PAYG system. Now they could decide on their own on the allocation of a part of their savings and were granted influence on the portfolio structure, both in

${ }^{3}$ Many of those beliefs seem, however, mistaken or exaggerated. See Barr and Diamond (2010, 2009) and Barr (2002) for more detailed elaboration and critical discussion. 
terms of bonds/stocks ratio and dispersion of risk granted by access to foreign markets. Individuals would also have stronger incentives for continuous participation in the labor market and for investments in skills and education, because the relation between contributions and benefits would be now more direct. Old-age consumption smoothing became thus more personalized and a matter of own foresight, weakening its link with societal developments and inter-generational redistribution.

The expansion of choice had its limits, though. Despite the fact that the system of individual capital accounts glorified personal responsibility and initiative, it remained mandatory in virtually all cases of reforming national pension systems. Pension savers were not allowed to opt-out in order to adopt their own saving schemes or to refrain from saving at all, thus taking full responsibility for their future. Leaving reasons for this coercive aspect aside, it should be emphasized that this solution implied that the state took the responsibility for designing the institutional framework of saving schemes and still bears, at least partially, responsibility for functioning and social results of the new system. The main underlying reason is that a market for pension funds is not a straightforward, competitive market like one for simple consumption goods. This is a market established and designed by government presumably with the intention to construct healthy microeconomic incentives for competition between funds, which should depend rather on price and quality of products than on exercise of market power or successful marketing measures, so that certain socially desired goals can be achieved, like old-age consumption smoothing or relatively secure pension saving. Yet, even with successful design, markets for pension funds have features of their own which differentiate them from other, more simple markets of choice and competition. For instance, as we could see in the previous paragraph, the participation on this market is mandatory for all the wage-earners and individual entrepreneurs, and as such they cannot abstain from pension saving within this particular framework. Demand for the product is guaranteed by the government, which makes it easier for the suppliers to sell, yet at the same time may induce reluctance or ignorance of buyers toward evaluation of offered options, even if their future incomes depend on it. These specific features of pension fund markets call then both for cautious design and continuous monitoring of developments.

The situation of individuals coerced to participate in the pension funds market is extraordinary as well. Most of all, an extensive choice invariably implies a trade-off: more choice equals more costs in terms of choosers' time, psychics and risk borne (Loewenstein, 1999). Even a partial shift from PAYG system to individual capital accounts involves increased dependency on financial markets, which display inherent uncertainty. This 
means that there is no safe investment strategy, and even seemingly similar strategies may bring mixed results depending on stock/bond portfolio or developments of particular markets. In effect, savers with the same history of contributions may receive very differentiated pension benefits. An obligatory system relying on choice imposes its adverse effects even on individuals that consciously abstain from making decisions: such savers are unintentionally drawn into comparisons and may experience feelings of anxiety caused by the fact that even no-choice implies an actual choice.

Moreover, when it comes to finances, people face a number of cognitive limitations as summarized by Barr and Diamond (2009), which add up to the limitations briefly described in the previous section. Individuals, for instance, tend to misunderstand uncertainties they face and options they are offered, they do not understand basic concepts of finance and complex systems of saving (like pension plans), they have difficulties with processing information of pension products even if they are provided with it (see also Lusardi \& Mitchell, 2011). In effect, the rising complexity of financial schemes and operations at the individual level has detrimental effects on personal involvement and results in disinterest, biased decisions and withdrawal from informed participation in saving programs. These psychological and cognitive factors of 'irrational' behavior are surprisingly common as reported by Fear (2008) in his study on Australia. Besides, it would be also very optimistic to assume that all citizens care about their pensions or that they do have preferences for saving schemes. Limited interest in pension saving may also be amplified by the fact that rewards of current foresight are usually located far in the future, which implies high uncertainty of the actual size of annuities, and at the same time fuels procrastination and negative perception of future consumption capacity.

Empirical investigations on pension systems that allow for extensive choice have confirmed many of the above reservations. Most of the literature refers to the case of $401(\mathrm{k})$ pension system in the United States which features high degree of voluntariness, but the results are nevertheless meaningful. Iyengar et al. (2004) found that the increasing number of options offered to pension savers leads to falling participation in these programs. For every ten funds added to the choice set, the number of participants fell by $1,5-2 \%$. In another study Iyengar and Kamenica (2010) observed that when faced with a large number of options, people not only refrain from participation, but also tend to choose simple, easy-to-understand options, even if these are more risky or inferior to other alternatives. Surprisingly, better options could have been chosen from a limited set of choice, indicating that the search for simplicity impairs our abilities to process data. Beshears et al. (2006) and Madrian and Shea (2001) reported significant 
inertia of sticking to the default saving scheme in terms of contribution rate, fund allocation, and post-saving distribution. This bias for status quo accentuates the procrastination issue and emphasizes the need for sound default schemes in saving programs, which have substantial impact on long-term saving outcomes. The importance of the default option design has also been confirmed by the comparative study of pension systems from ten countries differentiated by economic development level and cultural and historical background (Tapia \& Yermo, 2007).

\section{An Overview of the Swedish Pension Reform}

The new pension system was introduced in Sweden in 1999 as the previous defined-benefit system was found to be unsustainable in the long term for financial and demographical reasons. It also had structural flaws inter alia in being tied to the development of prices instead of the real economic growth or penalizing long working career and flat earnings profile over life time. The reform was expected to address these shortcomings and meet other goals, which can roughly be reduced to three basic premises that led the reform (Barr, 2013):

- the need to introduce a clear link between contributions and benefits with respect to fairness across generations,

- financial sustainability of the system should be achieved by tying it to economic growth and demographic change,

- individuals should be granted more choice in investing part of their savings.

Essentially, all these assumptions were met, at least in the pure design. The new rules for pensions have eliminated the regressive redistribution patterns of the old system. A brake mechanism was introduced in order to sustain the self-financing of the system, though at the cost of shifting the costs of adjustment on pensioners and pension savers. And finally, introduction of fully-funded premium pension system allowed individuals to make their own choice in funds' allocation, even though in a relatively limited scope. This paper focuses on the third aspect of the reform, which is the institutional arrangements of the choice given to pension savers and on the adverse effects of extensive choice possibilities. Yet, before we proceed 
with the analysis, it is worthwhile to briefly sketch the concept of the whole reform, so that the premium pensions can be viewed in a proper context ${ }^{4}$.

The previous pension system based on the pay-as-you-go principle provided a full pension after 30 years of contributions, based on worker's 15 best years. Its introduction in 1960 was perceived as a capstone of socialdemocratic welfare policies. The need for reform was realized already in 1980s, but it was only in 1990s that political circumstances were favorable enough to pursue necessary changes. The new system was designed in a cooperative manner by a parliamentary Pension Group consisting of the representatives of five parties representing ca. $85 \%$ of votes. The very essence of the reform was a change from defined-benefit principle into defined-contribution scheme. Final legislation was passed in 1998, and since 1999 the new system has been in power. It consists of three fundamental components:

- partially-funded notional defined contribution (NDC) pension scheme administered by the state (inkomstpension),

- fully-funded individual accounts, in which a pension saver is allowed to choose up to five privately managed funds to administer his savings (premiepension),

- the guaranteed pension providing poverty relief for those with insufficient history of contributions (garantipension).

The system is complemented with occupational and voluntary pension schemes, which however lie beyond the scope of state's direct responsibility. One ought to realize though that occupational pensions provide significant incomes for many workers, especially those with the history of high earnings (even up to $25 \%$ of future pensions).

The basic logic of the reformed pension system is following. Every month $18,5 \%$ of worker's earnings is transferred into the pension system. $16 \%$ goes to the NDC scheme forming the basic income pension and 2,5\% goes to individual accounts generating fully funded benefits. Both contributions are compulsory and collected by tax authorities. In order to receive full pension a contribution history of 40 years is required. The pension is calculated on the whole history of earnings, and one cannot retire earlier than at 61 years of age. There is no fixed retirement age, but one is no longer protected by the Employment Protection Act after turning 67. A pensioner is also allowed to withdraw his funds from individual capital account flexibly both in terms of timing and percentage of funds $(25 \%$, $50 \%, 75 \%$ or $100 \%$ ). This way capital left within funds still brings inter-

\footnotetext{
${ }^{4}$ For more detailed elaboration on the Swedish pension reform see Barr (2013), Palmer (2004), Palme (2005), Anderson (2006) or simply refer to the Pension Authority webpage www.pensionsmyndigheten.se.
} 
ests, but is exposed to market risk, whereas after withdrawal the funds are transferred into Pension Authority fund, which provides a fixed interest of $2,2 \%$ per year, yet with minimal risk. The new system also contains several microeconomic incentives for the development of labor market as its performance was considered crucial for the future of the system. One thus gets credits for rearing children and having tertiary education, whereas staying outside the labor market (for instance due to unemployment or sickness) or working part-time results in lower pension. People with insufficient contributions history are guaranteed a basic pension, or a supplement to the income pension, though one is eligible for full size basic pension only if they lived in Sweden for at least 40 years and have turned $65^{5}$.

Although the income pension has lost its fully redistributive character and the benefits are now more directly related to contributions, it is still based on a pay-as-you-go principle and cross-generational redistribution. However, the most progressive and far-reaching solutions concerned the premium pension system. This was largely a response to the critique of the previous system that was perceived as a vehicle for pensions' standardization and detrimental paternalism that deprived an individual of any influence on pension savings' management. Thus, the center-right parties insisted on giving it more individual tint, which would allow pension savers to make their own decisions and take more responsibility for their life as pensioners. It was also argued that individuals have the best knowledge of their own living and financial situation, and thus are capable of making allocative decisions suited best to their preferences with respect to risk and potential profits. In effect, the official aims of introducing the system were threefold (Socialdepartamentet, 2013, pp. 13-14):

- workers should be given opportunity to invest in the capital market in order to gain higher profits than an exclusively NDC system could provide. This way their future pension would not be limited only to the PAYG system which depends largely on GDP per capita growth,

- investments on the capital market would diversify the risk of receiving the pension solely from the PAYG system. This way, pensions would be less dependent on the developments in Swedish economy and demography, as well as in the sector of domestic economy one used to work in. The risk of Swedish economy would be minimized mostly by promoting investments on foreign capital markets,

- the freedom of choice would offer pension savers individualized risk and profit schemes. By making individual decisions concerning invest-

${ }^{5}$ In 2015 the guaranteed pension was 7046 SEK per month for a married person and 7899 SEK per month for a single person (ca. $30 \%$ of average salary). 
ments, one would adjust the expected profit to the bearable risk according to age, risk aversion, specific life situation etc.

As a result, pension funds market was created that offered pension savers the possibility to manage a part of their savings in line with their own preferences of risk, level of management fees and potential profits. One was allowed to choose up to five funds at the same time for the allocation of premium pension's contributions. It was expected that a reasonable individual would now follow the developments on his savings account and react accordingly so as to maximize future benefits and reduce the risk. Who would perform it better than the pension saver himself? The adverse effects of pay-as-you-go system and state's inefficiency would now be at least in part eliminated especially that the design of the system was also supposed to reduce some of commonly known market failures.

\section{The Choice Architecture of Swedish Premium Pension System and Its Results}

The pension funds market was worth almost 615 bln SEK in the end of 2013 and was still growing. It grouped 6,7 mln pension savers and pensioners and is eventually expected to grow to $7 \mathrm{mln}$ participants. As a result of the new legislation, in the fall of 200070 financial companies offered 4,4 mln Swedes 465 funds to choose from. The number of funds was growing steadily until 2006, when it stabilized at just below 800. However, in January 2015 there was already 843 funds offered to pension savers administered by 102 companies. Most of the funds invested in stocks (566), much less in bonds (145), and some had mixed stock and bond portfolios (98). In addition there were 34 funds with generational design.

Such a large number of funds was expected to match best the differentiated preferences of cohorts joining the system every year, just as theory suggested. It was realized, however, that such an extensive choice set could produce significant transaction costs of information gathering and processing, as well as a risk of being exposed to asymmetry of information and power between pension saver and fund managing companies. It was thus up to the 'choice architecture' whether these effects would actually appear or how strong they would be. A careful design of the premium pension system could eliminate, or at least mitigate some of the factors causing the choice overload phenomenon.

There are at least four features worth mentioning in this context. First and foremost, Pension Authority (Pensionsmyndigheten) was established to act like a clearinghouse and a middleman between pension savers and man- 
aging companies. It groups together all the requests to join particular funds, withdraw capital, change the investment fund etc. and executes them jointly. This means that it is Pension Authority that is allocating capital into pension funds, not individual pension savers. This has several important consequences (see: Palmer, 2004), but relevant to our study is that savers' legal and institutional position against the pension fund is significantly strengthened and thus countervails a potential asymmetry of power. Savers are also anonymous to managing companies and hence free of being subject to adverse selection practices or various marketing-related pressures. All pensions are also paid out by Pension Authority, not by private sector funds. Secondly, all relevant information concerning funds (portfolio structure, history of results, costs of management etc.) has been available since the beginning of the system at any time at the Pension Authority webpage contributing to the creation of extensive and reliable access to information, favoring high transparency and offering a possibility of making unproblematic comparisons between funds. This way an important step towards reducing transaction costs of information gathering and processing has been made. Thirdly, a pension saver is allowed to change funds every day at no charge. One is thus allowed to allocate one's pension capital freely with no fees or legal limitations put against him by managing companies. The factor of time is also made insignificant as one has as much time as one wishes to make a firm decision and execute it instantly. Thanks to the possibility of choosing up to five funds at once, one does not have to commit to one fund only. And fourthly, because the Pension Authority acts as a clearinghouse and pools all individual allocation decisions, it demands significant rebates from pension funds for managing pension capital compared to the fees charged on voluntary transactions. Pension system is thus cost-competitive toward traditional capital market and cannot differentiate between pension savers.

At the beginning, the effects were promising. In fall of 2000, when pension savers were first offered a choice, $67 \%$ of individuals made one. Those that did not, were transferred into state's administered fund AP7 Såfa. However, 67\% was the best result the system ever achieved (see Table 1) as the percentage of newcomers that committed a deliberate choice began to fall steeply and since 2007 holds at 1,6\% level. In 2000 it was a breath of novelty: after a long political struggle for introducing choice into pension systems individuals were granted one and so many committed to making a deliberate choice. It was also a time of massive media campaign encouraging pension savers to choose for themselves and stressing that a proper choice will make a decent pension. Later the campaign faded away as much fewer people were joining the system, usually at the beginning of their ca- 
reers and so with very small capital to administer. The falling involvement in making a thoughtful choice contrasts with the rising number of investment funds (Figure 1). Between 2000 and 2006 the number of funds rose to almost 800 , but this rather discouraged than stimulated potential choice makers. Recent rise to 850 funds probably did not help either.

Table 1. Percentage of newcomers making an active choice

\begin{tabular}{ccccc}
\hline Year & Total $(\boldsymbol{\%})$ & Women $(\boldsymbol{\%})$ & Men $(\boldsymbol{\%})$ & New savers (thousands) \\
\hline 2000 & 67,0 & 68,0 & 66,0 & 4420 \\
\hline 2001 & 18,0 & 18,2 & 16,8 & 493 \\
\hline 2002 & 14,0 & 14,0 & 14,3 & 196 \\
\hline 2003 & 8,4 & 8,4 & 8,3 & 150 \\
\hline 2004 & 9,4 & 9,3 & 9,5 & 129 \\
\hline 2005 & 8,0 & 8,3 & 7,7 & 117 \\
\hline 2006 & 7,4 & 7,4 & 7,5 & 115 \\
\hline 2007 & 1,6 & 1,6 & 1,7 & 133 \\
\hline 2008 & 1,6 & 1,4 & 1,8 & 183 \\
\hline 2009 & 1,6 & 1,5 & 1,8 & 178 \\
\hline 2010 & 1,6 & 1,4 & 1,7 & 129 \\
\hline 2011 & 1,5 & 1,4 & 1,7 & 172 \\
\hline 2012 & $<2$ & & &
\end{tabular}

Source: Socialdepartamentet (2013, p. 28); Pensionsmyndigheten (2013, 2014).

Another factor that may have contributed to the falling number of active choice makers was that the rate of return on capital was highly negative (see Figure 2). 100 SEK put into the system in 2000 was worth on average less than 60 SEK two years later. Even though market recovered during following years, it plummeted again in 2008-2009 - the same 100 SEK was now worth below 80 SEK. This situation showed that individual choice in fact did not matter against overwhelming market forces, so why bother with time-consuming and stressful choice if the result was negative anyway? On top of all, even if the rate of return was generally positive at the end of 2000-2013 period, it was still below the accumulated growth rate of the income pension based on PAYG principle. The notional defined contribution system generated thus higher returns for individuals than stock and bond markets during 13-years' period. In 2014 the situation finally reversed, but no one can guarantee that there will be no downturn again. This explicitly highlights the risk involved in retiring at the wrong moment when markets are contracting and accumulated savings are thawing. 
Figure 1. Number of funds and active choice

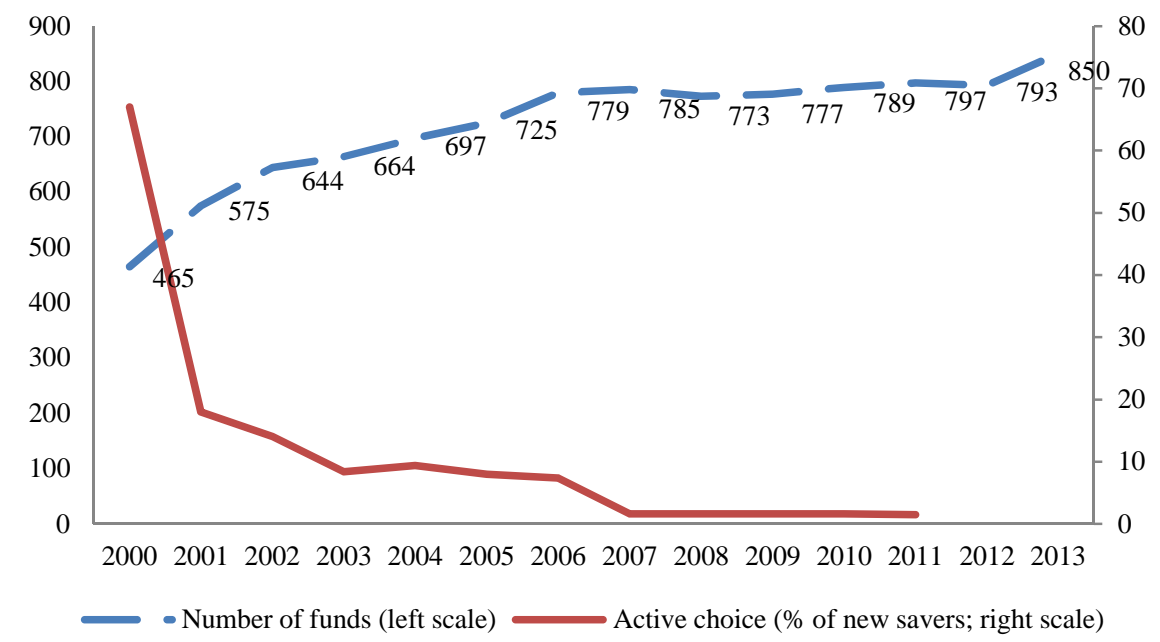

Source: own calculations.

Figure 2. Value of 100 SEK paid into income and premium pension systems compared to the developments on Stockholm Stock Exchange

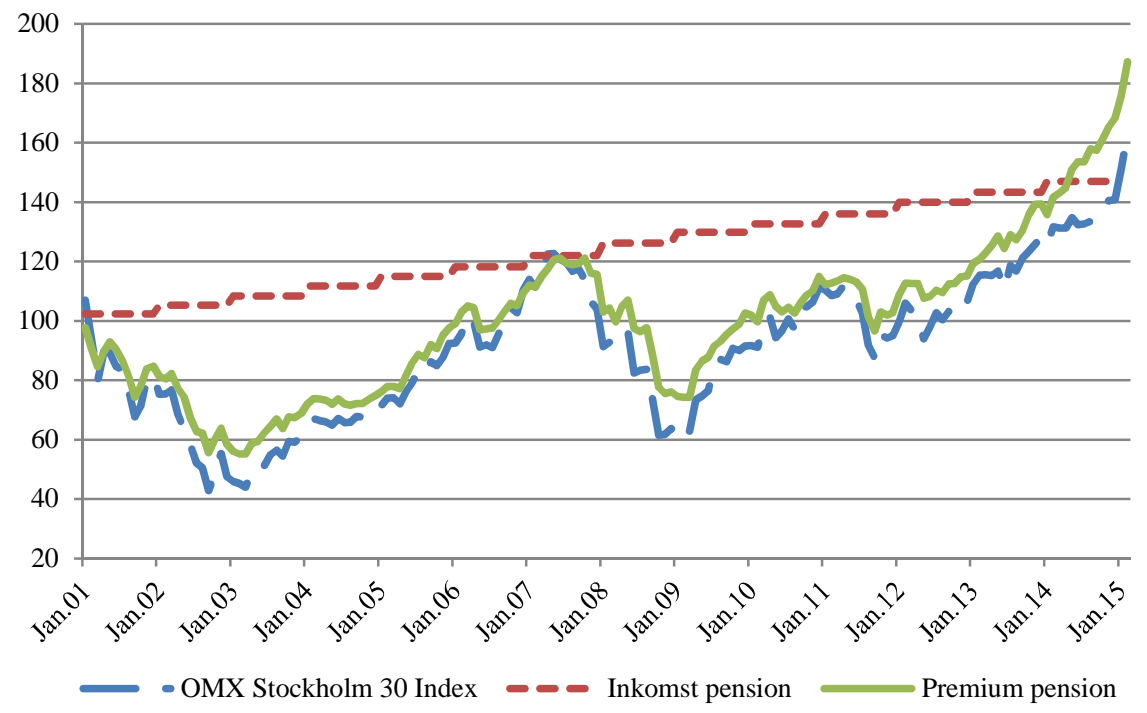

Source: own calculations based on Pension Authority statistics, OMX Stockholm 30 Index and Pensionsmyndigheten (2014a, p. 45). 
Statistical data confirms that most pension savers are not interested in managing their accounts (see Table 2). No more than $7 \%$ of savers made at least one change per year in their portfolios under 2000-2011 period. 51\% of savers have never bothered to choose managing fund and were automatically transferred into AP7 Såfa fund. 20\% of savers made an active choice once, but have been passive since that time, and $22 \%$ made less than one change per year. There is a possibility to deliberately choose AP7 Såfa or one of its subfunds (cautious, balanced or aggressive), which could explain the high participation rate in the state administered fund, but out of $3,1 \mathrm{mln}$ participants only 142 thousands intentionally made such a decision until the end of 2013 (Pensionsmyndigheten, 2014). 2,76 mln savers were transferred there because they have withdrawn from making any choice and 174 thousand due to inaction when their preferred fund was terminated.

Table 2. Average yearly activity of pension savers until 31.12.2011

\begin{tabular}{cccc}
\hline \multirow{2}{*}{ Activity } & $\begin{array}{c}\text { Choice/No. of } \\
\text { changes per year }\end{array}$ & $\begin{array}{c}\text { Pension savers } \\
\text { (thousands) }\end{array}$ & Percentage \\
\hline Inactive & AP7 Såfa & 2664 & 51 \\
\hline \multirow{3}{*}{ Low activity } & $\begin{array}{c}\text { Chosen once, never } \\
\text { changed }\end{array}$ & 1082 & 20 \\
\cline { 2 - 4 } & Less than 1 change & 1156 & 22 \\
\cline { 2 - 4 } & $1-2$ & 195 & 4 \\
\cline { 2 - 4 } & $2-3$ & 105 & 2 \\
\cline { 2 - 4 } Active & $3-4$ & 49 & 0 \\
\cline { 2 - 4 } & $4-5$ & 18 & 0 \\
\cline { 2 - 4 } & $5-6$ & 10 & 0 \\
\cline { 2 - 4 } & $6-7$ & 6,7 & 0 \\
\cline { 2 - 4 } & $7-8$ & 3,9 & 100 \\
\hline
\end{tabular}

Source: Socialdepartamentet (2013, p. 58).

Weaver (2004) reported results of polls which tried to find out the rationale behind this kind of adverse behavior when the system took off. The most popular answers in 2004 were as follows. 28\% of non-choosers claimed that they had no time or energy to make a choice; $18 \%$ were simply not interested in making any choice; $13 \%$ did not have sufficient knowledge to make an active choice; $14 \%$ believed that they still got much time until retiring and $10 \%$ felt that they had too little money to make any difference. Similar answers were noticed within the group that deliberately chose AP7 fund. $24 \%$ did not have the energy or want to choose; $24 \%$ 
wanted to be spared choice for now; $21 \%$ felt that they had too little information to make a choice; $17 \%$ had too little money; $13 \%$ felt that AP7 is safe and secure and only $6 \%$ thought that the results of the fund were good. A study by Palme and Sunden (2004) confirmed that the broad choice offered was rather pacifying, not stimulating, and that many individuals misunderstood or did not wish to take advantage of the features offered by the new system. Pension savers hardly diversified the risk; they tended to invest in home economy or even in a particular branch of economy, possibly the one they worked in. Many have also decided to make choice 'once and forever'.

Recent research have largely confirmed that the Swedes do not feel comfortable in this particular field of decision making. A report by Social Insurance Inspectorate (Inspektionen, 2013) showed that individuals in Sweden have very limited knowledge on pensions and pension saving system, even though they are provided with extensive information by authorities. It turns out that information campaigns performed by the Pension Authority have had very limited effect on increasing this knowledge in the long-run. This knowledge is, however, positively related with age, incomes, and education. Almenberg (2011) has reported on deficiencies in financial literacy in Sweden. Even if simple calculations gave satisfactory results, more complicated ones (like understanding compound interest) caused much more trouble. Many Swedes also have poor understanding of basic financial instruments. It is thus little wonder that a significant percentage of Swedes do not feel competent to make decisions that will determine their old-age economic security, and so prefer to rely on the state or simply postpone the decision into future. Not everybody wishes to be a financial expert anyway - one could also doubt if it would be socially profitable. Was it not the principle of specialization and a division of labor that spurred economic success of the West?

The Swedish case described above indicates two important points so far. The first is that the Swedish premium pension system is burdened with choice overload paradox even though many measures have been taken to at least partly mitigate this effect. Homo economicus turned out to be human again, with all the consequences involved. His cognitive abilities proved to be very limited and he acted according to his temporary feelings and changing preferences as well as biases towards status quo or procrastination.

The second point is that having a decent default option is of key importance when so many individuals abstain from making a deliberate choice. There is, of course, a possibility to randomly distribute those pension savers among the existing funds, forcing them to join private-sector administration (that kind of policy works for example in Poland), but it 
seems rather unjust and unethical. Pension funds have various rates of return and therefore two persons with equal contributions' history could end up with different pension benefits although none had made any active choice. Understandably, this caveat does not apply to voluntary participation in premium pension. A very similar case has actually been touched upon by recent government report, indicating that the premium pension system will probably produce higher pension inequalities than expected (Socialdepartamentet, 2013). An extreme example shows that for a very small number of individuals there is a difference of 25 percentage points in the average rate of return since the introduction of the system: $0,01 \%$ of pension savers got annual rate of $-8 \%$ and $0,02 \%$ of $+17 \%$. If this trend continues, the first group is expected to receive 1000 SEK of premium pension per month and the second group up to 200000 SEK per month when retired. However, $95 \%$ of pension savers had the rate of return within $-1 \%$ and $+6 \%$ brackets. But even here the difference can be substantial: 3000 versus 10000 SEK per month. Apart from rising inequality, this situation also increases the risk of old-age poverty for a number of pension savers and can even be amplified by an unfortunate moment of retiring when markets contract.

The Swedish default pension fund AP7 Såfa seems to be a very reasonable alternative to staying at private sector pension funds. It produced an average yield of $6,2 \%$ for $1995-2013$ period, whereas an average pension fund only 4,8\%. In 2013 the difference was exceptionally huge: $26,6 \%$ in AP7 compared to $16,7 \%$ in privately managed funds (Pensionsmyndigheten 2014). Such a favorable outcome for the state-administered fund can be attributed to the fact that as much as $90 \%$ of its assets consists of stock holdings (of which only $10 \%$ of Swedish shares), whereas in private funds less than $80 \%$. AP7 Såfa is therefore more profitable, yet burdened with higher risk at the same time. An important feature is that in 2013 the public fund enjoyed management cost of $0,12 \%$ of accumulated capital every year compared to an average of $0,39 \%$ in privately managed funds. The costs of state's management are thus much lower than in the private sector, even after the negotiated rebates. One has to remember though that even the state administered fund is vulnerable to markets' instability and it produced negative results in the same years as private pension funds did. It confirms, however, that the state is able to provide a decent substitute to the private sector even within the exiting paradigm of fully funded individual capital accounts. Such a common default fund is also a more ethical solution, which can minimize pension inequalities and the risk of old-age poverty if carefully designed. 
It is worth mentioning before concluding that the shortcomings of the existing choice architecture have not gone unnoticed, and the Swedish government is preparing a reform. The recent report (Socialdepartamentet, 2013) indicated that there is a serious threat of arriving at socially unacceptable inequalities of pensions coming from the premium system and that too many individuals feel overwhelmed with choice options. The report points to the very limited knowledge on pensions among pension savers and an extensive number of funds as underlying causes of these developments. It also sketches two possible scenarios for the government to follow. The first assumes staying within the same paradigm of choice leaving the huge number of options available. It will, however, overtly promote the default solution for those that not wish to make a choice, as well as impose cost and risk limits on private funds so as to lessen the issue of future annuities' inequality. The second scenario breaks off with the extensive choice and assumes introduction of a limited number of funds (possibly ten). The default alternative will stay in power. These proposals are currently under detailed investigation by the parliamentary Pension Group and a final report is expected to be presented in September 2015 (Finansdepartamentet, 2014). Interestingly, the report openly admits that scenario analyses are essentially questions of values that constitute government's priorities and expectations of specific results. Efficiency of institutional solutions are here of secondary meaning as it is largely easy to estimate the costs and benefits of the changes. Here it is rather a trade-off between broad old-age security and the current freedom of choice. It is government's task and responsibility to decide which one to choose.

\section{Conclusions}

The case of the Swedish premium pension system confirms that an extensive choice leads to choice deferral and a preference for staying at status quo even in situation of paramount importance for one's future economic security. These findings are hardly new in the light of choice overload literature. However, the occurrence of choice overload in the field of public policy is a rather new phenomenon and implicates new issues to reflect on. A democratic public policy ought to ensure - at least in principle - that more choice should bring about more efficient delivery of welfare and should not foster increase of inequalities. And therefore even the privatized system of public policy should be under constant observation of democratic government and adjusted in line with the adopted values and principles of social life. 
Government's responsibility invokes the question of choice architecture: who it was designed for and what principles it was based on. Both in theory and in praxis, as the Swedish case shows. The premium system has been designed with rationally perceived interest of a pension saver in mind. It does the utmost to equip him with plenty of relevant information, allows for frequent and costless change of funds, aims at far-reaching reduction of administrative costs and protects his identity. And in doing so, it mitigates the acknowledged effects of market failures and choice overload. Alas, flaws in this careful construction appeared when pension savers turned out not to be perfectly rational agents and the measures that were supposed to facilitate the choice decision process proved pretty useless. This brings a lesson that a design based on rational choice is not everything. Policymakers should rely more on findings in psychology than mainstream economic theory to design tools efficient enough to remedy market failures. As Madrian (2014) recently argued, it is very often not about the inefficiencies of market structure or wrong incentives that make certain solutions fail - it could well be about human nature. Effective public policy should take this into account, even if it could be politically incorrect.

The Swedish case illustrates one more unintended effect of a theoretically well-designed public policy. It could happen that the falling number of active choosers, if not countervailed, will end up in a situation that the premium pension system was introduced only to benefit a small number of pension savers at the expense of majority. For the sake of giving the former freedom of choice and flexibility of allocation, the security of savings for the whole population has dropped. In turn, this can result in erosion of social solidarity and increased risk of old-age poverty. Current attempts to reform the system prove that government wants to resolve this problem before it gets too far. The forthcoming public discussion will show, however, if those that benefit on the new system are already strong enough to kill the reforming efforts.

\section{References}

Almenberg, J. (2011). Räknefärdighet och finansiell förmåga. Ekonomisk Debatt $39(5)$.

Anderson, C. J. (2003). The Psychology of Doing Nothing: Forms of Decision Avoidance Result from Reason and Emotion. Psychological Bulletin, 129(1). DOI: http://dx.doi.org/10.1037/0033-2909.129.1.139. 
Anderson, K. M. (2006). Pension Reform in Sweden: Radical Reform in a Mature Pension System. In G. Bonoli \& T. Shinkawa (Eds.). Ageing and Pension Reform Around the World. Evidence from Eleven Countries. Cheltenham: Edward Elgar.

Barr, N. (2002). Reforming Pensions: Myths, Truths, and Policy Choices. International Social Security Review, 55(2). DOI: http://dx.doi.org/10.1111/1468246X.00122.

Barr, N. (2013). The Pension System in Sweden. Report to the Expert Group on Public Economics. Stockholm: Ministry of Finance.

Barr, N. A., \& Diamond, P. (2009). Reforming Pensions: Principles, Analytical Errors and Policy Directions. International Social Security Review, 62(2). DOI: http://dx.doi.org/10.1111/j.1468-246X.2009.01327.x.

Barr, N. A., \& Diamond, P. A. (2010). Pension Reform. A Short Guide. New York: Oxford University Press.

Blomqvist, P. (2004). The Choice Revolution: Privatization of Swedish Welfare Services in the 1990s. Social Policy \& Administration, 38(2). DOI: http://dx.doi.org/10.1111/j.1467-9515.2004.00382.x.

Botti, S., \& Iyengar, S. S. (2006). The Dark Side of Choice: When Choice Impairs Social Welfare. Journal of Public Policy \& Marketing, 25(1). DOI: http://dx.doi.org/10.1509/jppm.25.1.24.

Dhar, R. (1997). Consumer Preference for a No-Choice Option. Journal of Consumer Research, 24(2).

Ebbinghaus, B. (2011). The Varieties of Pension Governance. Pension Privatization in Europe. Oxford, New York: Oxford University Press.

Fear, J. (2008). Choice Overload. Australians Coping with Financial Decisions. Australia Institute Discussion Paper, no. 99.

Finansdepartementet (2014). Kommittédirektiv 2014:107 Ett reformerat premiepensionssystem.

Gilboa, I. (2010). Rational Choice. Cambridge. Mass: MIT Press.

Greve, B. (2003). When Choice is Possible in Social Security? European Journal of Social Security, 5(4).

Greve, B. (2009). Can Choice in Welfare States Be Equitable? Social Policy \& Administration, 43(6). DOI: http://dx.doi.org/10.1111/j.1467-9515.2009. 00679.x.

Hausman, D. M. (2012). Preference, Value, Choice, and Welfare. Cambridge, New York: Cambridge University Press.

Haynes, G. A. (2009). Testing the Boundaries of the Choice Overload Phenomenon: The Effect of Number of Options and Time Pressure on Decision Difficulty and Satisfaction. Psychology and Marketing, 26(3). DOI: http://dx.doi.org/ 10.1002/mar.20269.

Inbar, Y., Botti, S., \& Hanko, K. (2011). Decision Speed and Choice Regret: When Haste Feels Like Waste. Journal of Experimental Social Psychology, 47(3). DOI: http://dx.doi.org/10.1016/j.jesp.2011.01.011. 
Inspektionen för socialförsäkringen (2013). Kunskapsmätning 2012. Kartläggning av pensionsspararnas kunskaper om det allmänna pensionssystemet. Arbetsrapport 2013:1.

Iyengar, S. S., Jiang, W., \& Huberman, G. (2004). How Much Choice is Too Much? Contributions to 401(k) Retirement Plans. In O. S. Mitchell \& S. P. Utkus (Eds.). Pension design and structure. New lessons from behavioral finance. Oxford, New York: Oxford University Press.

Iyengar, S. S., \& Kamenica, E. (2010). Choice Proliferation, Simplicity Seeking, and Asset Allocation. Journal of Public Economics, 94(7-8). DOI: http://dx.doi.org/10.1016/j.jpubeco.2010.03.006.

Iyengar, S. S., \& Lepper, M. R. (2000). When Choice Is Demotivating: Can One Desire Too Much of a Good Thing? Journal of Personality and Social Psychology, 79(6). DOI: http://dx.doi.org/10.1037//0022-3514.79.6.995.

Jessup, R. K., Veinott, E. S., Todd, P. M., \& Busemeyer, J. R. (2009). Leaving the Store Empty-handed: Testing Explanations for the Too-much-choice Effect Using Decision Field Theory. Psychology and Marketing, 26(3). DOI: http://dx.doi.org/10.1002/mar.20274.

LeGrand, J. (2007). The Politics of Choice and Competition in Public Services. Political Quarterly, 78(2). DOI: http://dx.doi.org/10.1111/j.1467923X.2007.00848.x.

Leotti, L. A., Iyengar, S. S., \& Ochsner, K. N. (2010). Born to Choose: The Origins and Value of the Need to Control. Trends in Cognitive Sciences, 14(10). DOI: http://dx.doi.org/10.1016/j.tics.2010.08.001.

Loewenstein, G. (1999). Is More Choice Always Better? Social Security Brief. National Academy of Social Insurance Working Paper, 7.

Lusardi, A., \& Mitchell, O. S. (2011). Financial Literacy and Planning: Implications for Retirement Wellbeing. NBER Working Paper Series, No. 17078.

Lynch, J. G., \& Zauberman, G. (2006). When Do You Want It? Time, Decisions, and Public Policy. Journal of Public Policy \& Marketing, 25(1). DOI: http://dx.doi.org/10.1509/jppm.25.1.67.

Madrian, B. C., \& Shea, D. F. (2001). The Power of Suggestion: Inertia in 401(k) Participation and Savings Behavior. Quarterly Journal of Economics, 116(4). DOI: http://dx.doi.org/10.1162/003355301753265543.

Madrian, B. C. (2014). Applying Insights from Behavioral Economics to Policy Design. Annual Review of Economics, 6. DOI: http://dx.doi.org/10.1146/ann urev-economics-080213-041033.

Madrian, B. C., Beshears, J., Choi, J. J., \& Laibson, D. (2006). The Importance of Default Options for Retirement Savings Outcomes. Evidence from the United States. NBER Working Paper Series, No. 12009.

Masatlioglu, Y., \& Ok, E. A. (2005). Rational Choice with Status Quo Bias. Journal of Economic Theory, 121(1). DOI: http://dx.doi.org/10.1016/j.jet.2004.03. $\underline{007}$.

O'Boyle, E. J. (2007). Requiem for Homo Economicus. Journal of Markets \& Morality, 10(2). 
Palme, J. (2005). Features of the Swedish Pension Reform. Japanese Journal of Social Security Policy, 4(1).

Palme, M., \& Sunden, A. (2004). Premiepensionen i det reformerade pensionssystemet - är det önskvärt att kunna välja mellan 663 fonder? Ekonomisk Debatt, 32(3).

Palmer, E. (2004). Sweden's New FDC Pension System. Paper presented at seminar Desafios del Sistema Chileno de Pensiones Competencia, Santiago, Chile.

Pensionsmyndigheten (2013). Premiepensionen. Pensionsspararna och pensionärerna 2012.

Pensionsmyndigheten (2014). Premiepensionen. Pensionsspararna och pensionärerna 2013.

Pensionsmyndigheten (2014a). Orange Report. Annual Report of the Swedish Pension System 2013.

Pierson, C. (2006). Beyond the Welfare State? The New Political Economy of Welfare. Cambridge: Polity.

Reed, D. D., DiGennaro Reed, F. D., Chok, J., \& Brozyna, G. A. (2011). The "Tyranny of Choice": Choice Overload as a Possible Instance of Effort Discounting. Psychological Record, 61(4).

Reutskaja, E., \& Hogarth, R. M. (2009). Satisfaction in Choice as a Function of the Number of Alternatives: When "Goods Satiate". Psychology and Marketing, 26(3). DOI: http://dx.doi.org/10.1002/mar.20268.

Sagi, A., \& Friedland, N. (2007). The Cost of Richness: the Effect of the Size and Diversity of Decision Sets on Post-decision Regret. Journal of personality and social psychology, 93(4). DOI: http://dx.doi.org/10.1037/0022-3514.93.4.515.

Samuelson, W., \& Zeckhauser, R. (1988). Status Quo Bias in Decision Making. Journal of Risk and Uncertainty, 1(1).

Satz, D., \& Ferejohn, J. (1994). Rational Choice and Social Theory. The Journal of Philosophy, 91(2).

Scheibehenne, B., Greifeneder, R., \& Todd, P. M. (2009). What Moderates the Too-much-choice Effect? Psychology and Marketing, 26(3). DOI: http://dx.doi.org/10.1002/mar.20271.

Scheibehenne, B., Greifeneder, R., \& Todd, P. M. (2010). Can There Ever Be Too Many Options? A Meta-Analytic Review of Choice Overload. Journal of Consumer Research, 37(3). DOI: http://dx.doi.org/10.1086/651235.

Schotter, A. (2009). Microeconomics. A Modern Approach. Mason, OH: SouthWestern Cengage Learning.

Schwartz, B. (2004). The Paradox of Choice. Why More is Less. New York: Ecco.

Socialdepartementet (2013). Departamentsserien 2013:35 Vägval för premiepensionen.

Solnick, S. J., \& Hemenway, D. (1998). Is More Always Better?: A Survey on Positional Concerns. Journal of Economic Behavior \& Organization, 37(3). DOI: http://dx.doi.org/10.1016/S0167-2681(98)00089-4.

Thaler, R. H. (2000). From Homo Economicus to Homo Sapiens. Journal of Economic Perspectives, 14(1). DOI: http://dx.doi.org/10.1257/jep.14.1.133. 


\section{4}

Thaler, R. H., \& Sunstein, C. R. (2009). Nudge. Improving Decisions About Health, Wealth, and Happiness. New York: Penguin Books.

Timmermans, D. (1993). The Impact of Task Complexity on Information Use in Multi-attribute Decision Making. Journal of Behavioral Decision Making, 6(2). DOI: http://dx.doi.org/10.1002/bdm.3960060203.

Tversky, A., \& Shafir, E. (1992). Choice Under Conflict: The Dynamics of Deferred Decision. Psychological Science, 3(6).

Vohs, K. D., Baumeister, R. F., Schmeichel, B. J., Twenge, J. M., Nelson, N. M., \& Tice, D. M. (2008). Making Choices Impairs Subsequent Self-control: A Limited-resource Account of Decision Making, Self-regulation, and Active Initiative. Journal of Personality and Social Psychology, 94(5). DOI: http://dx.doi.org/10.1037/0022-3514.94.5.883.

Weaver, R. K. (2004). Design and Implementation Issues in Swedish Individual Pension Accounts. Social Security Bulletin, 65(4).

Wilkinson, N. (2008). An Introduction to Behavioral Economics. New York: Palgrave Macmillan.

Winston, P., Burwick, A., McConnell, S., \& Roper, R. (2002). Privatization of Welfare Services: A Review of the Literature. Mathematica Policy Research Report, Princeton.

Yermo, J., \& Tapia, W. (2007). Implications of Behavioural Economics for Mandatory Individual Account Pension Systems. OECD Working Papers on Insurance and Private Pensions, 11. 